\title{
Current subjects on endophyte toxicosis
}

\author{
Shigeru MIYAZAKI \\ Toxico-Biochemistry Section, Department of Safety Research, \\ National Institute of Animal Health, NARO \\ (3-1-5 Kannondai, Tsukuba 305-0856, Japan)
}

Key words: Iolitrem, ergovaline, ergot alkaloids, perenrial ryegrass, tall fescue

(Received: August 2, 2002)

\section{Introduction}

The term endophyte has been defined as an organism growing symbiotically in the plants. In the field of animal industry, the term endophyte has been used to indicate a group of fungi that infect to grasses. In grasses, endophyte produces biologically active substances that provide benefits to the plants. However, the specific endophytes produce compounds toxic to animals. Toxicoses in livestock that have grazed on Neotyphodium-infected grasses are well known as ryegrass staggers and fescue toxicosis ${ }^{1)}$. Lolitrems ${ }^{2)}$, primarily lolitrem B (Fig. 1a), found in N. Iolii-infected perennial ryegrass (Lolium perenne) have been implicated as the causative toxin of ryegrass staggers ${ }^{3)}$. Lolitrems are neurotoxic and induce a nervous disorder of sheep ${ }^{4)}$, cattl $\mathrm{e}^{5}$ and horses ${ }^{6}$. As for fescue toxicosis, ergot alkaloids, primarily ergopeptine alkaloid ergovaline ${ }^{7}$ (Fig. 1b), detected in N. coenophialuminfected tall fescue (Festuca arundinacea) have been shown to have pharmacological effects ${ }^{8,9}$. The toxic effects include poor weight gain, low milk production, poor reproduction, gangrenes of hooves, ear tips and tail tip, necrosis of the peritoneal fat tissue, depressed immune response and direct endocrine effects ${ }^{10)}$.

For the prevention of endophyte toxicosis, we have been importing endophyte-free seeds of pasture-type perennial ryegrass and tall fescue. On the other hand, the fungal endophyte has been introduced into turf-type perennial ryegrass and tall fescue to enhance plant hardiness, pest resistance, and drought tolerance.

\section{Endophyte toxicosis in Japan}

From 1997 to 1999, we experienced 29 cases of disorders in cattle and horses fed imported ryegrass straw. The place of origin of the straw was Oregon, USA, when the origin was indicated. The affected animals showed symptoms resembling ryegrass staggers. In the mild cases, the affected animals showed head tremors, hyperesthesia and a staggering gait. Severely affected animals showed tremors of the general musculature, falling down after staggering, and tetanic spasms. Serum AST, CK and LDH activities of severely affected animals were higher than those of normal animals ${ }^{11,12)}$. 
a)

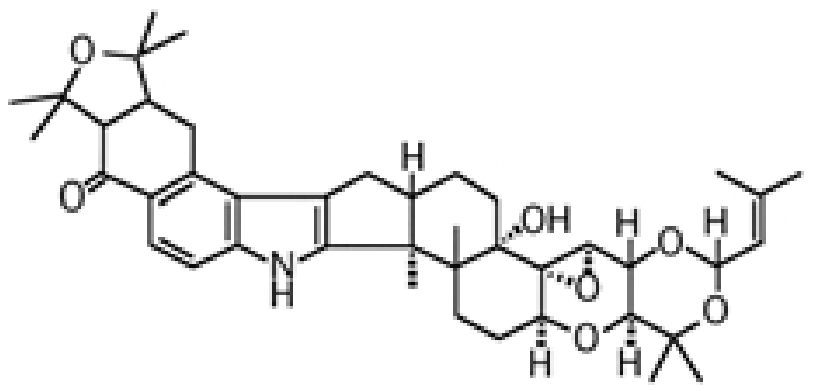

b)

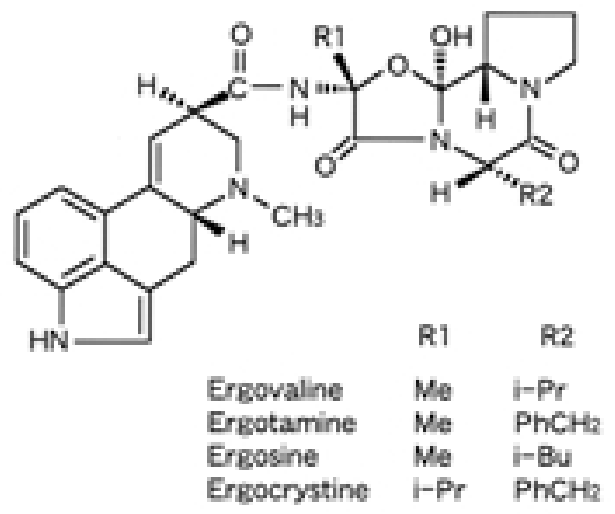

Figure 1. Structure of endophyte toxins

a) Iolitrem $B$

b) ergopeptine alkaloids

These clinical signs were consistent with those of a previous report for ryegrass staggers ${ }^{13)}$.

Ryegrass or fescue straw is a by-product of turf-type grass seed production in the US. Because of restrictions on field burning, grass seed producers, who once got rid of their straw by burning it in the fields after harvest, have been selling it for livestock feed. As mentioned in previous section, fungal endophytes have been introduced into turf-type perennial ryegrass and tall fescue to enhance plant hardiness, pest resistance, and drought tolerance. Therefore, it was expected that most of the imported straw contains endophyte toxins to some degree.

To clarify the cause of disorders in cattle, we examined the suspected straw for the presence of endophytic hyphae (Fig. 2) and lolitrem B. Lolitrem B concentrations in the suspected straws ranged between $972 \mathrm{ppb}$ and $3740 \mathrm{ppb}$. The threshold levels of lolitrem B for toxicity were reported as 1800$2000 \mathrm{ppb}$ in the total diet ${ }^{14}$. In all cases that we examined, other feeds such as formula feeds were fed with the straw. Therefore, the final concentrations of lolitrem $B$ in the total diets should have been lower than the values indicated above. Even though the concentrations of Iolitrem B were lower than the proposed threshold in almost all clinical cases, endophyte-infected perennial ryegrass straw was suspected as the cause of the disorders from the clinical signs and epidemiological findings $\mathrm{s}^{15}$. The sensitivity of the cattle to the endophyte toxins might be due to differences between strains, ages, 


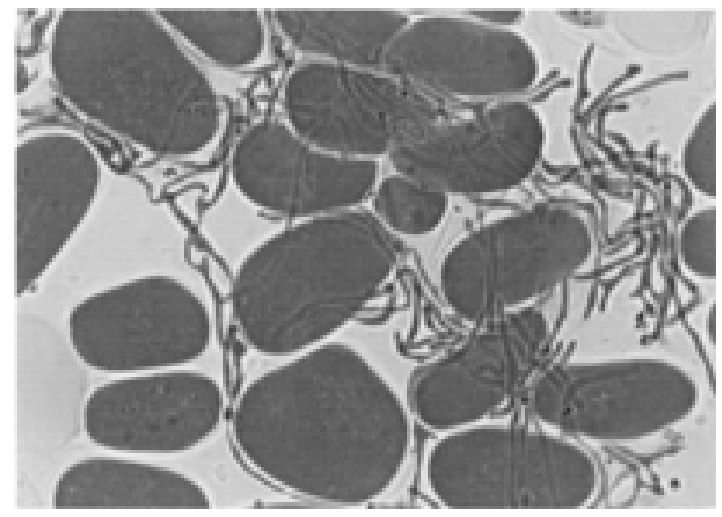

Figure 2. Endophytic hyphae seen between the aleurone cells of a perennial ryegrass seed. (x400)

sexes or other factors. The sensitivity of Japanese Black cattle to Iolitrem B toxicity might be higher than the other strains of cattle.

\section{Measures for the prevention of endophyte toxicosis}

We showed that perennial ryegrass straw imported from the US, especially from Oregon, contained endophyte toxins and the toxins are suspected as being the main cause of some clinical disorders. On the other hand, ryegrass or fescue straw demand as feed is growing. Import of rice straw from Taiwan and Korea was banned because of the occurrence of foot and mouth disease in those areas. Ryegrass and fescue straws are imported as cheap alternatives for rice straw. As mentioned in previous section, the threshold levels of endophyte toxins in the straw were proposed by the Oregon State University for the prevention of endophyte toxicosis. As an interim measure for the prevention of the disorders, import companies have been requesting information on the concentration of the toxins. These companies are importing ryegrass straw only when the concentrations of lolitrem B and ergovaline are lower than the proposed thresholds. Fertilizer and Feed Inspection Station of Japan has been monitoring the concentration of endophyte toxins in imported straw. Their survey shows that almost all of imported straw contains toxins lower than the proposed threshold.

\section{Susceptibility of J apanese B lack Cattle to Lolitrem B}

Despite the measures mentioned in the previous section, we are still facing the ryegrass staggers caused by imported straw. As mentioned in 'Endophyte Toxicosis in Japan', Japanese Black cattle might be susceptible to ryegrass staggers. We performed the feeding experiment to examine the sensitivity of the Japanese Black cattle to lolitrem B by using the perennial ryegrass straw containing $1200 \mathrm{ppb}$ of lolitrem B. Nine Japanese Black cows were divided into three groups. First group was fed the straw ad libitum. They consumed about $6.5 \mathrm{~kg}$ of straw a day. Second group received $3 \mathrm{~kg}$ of straw a day. Third group was kept as control with the other roughage. All three 


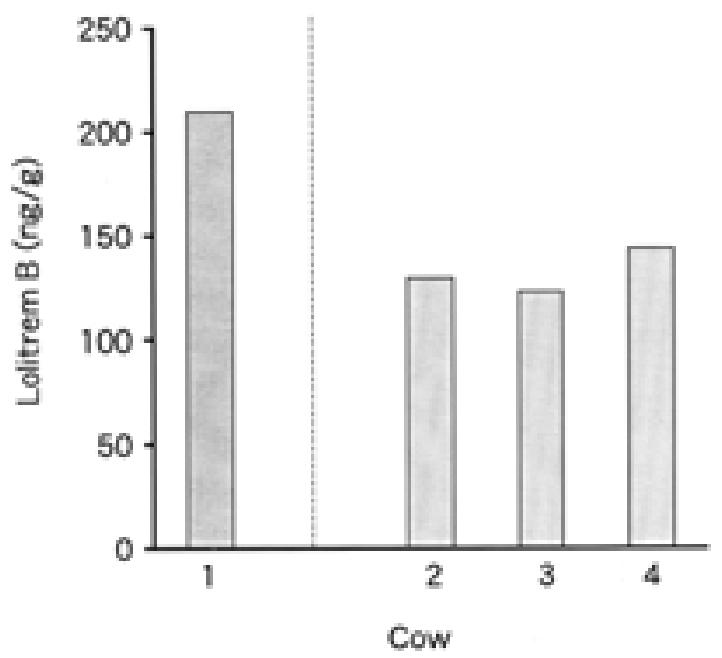

Figure 3. Concentration of lolitrem B in fat tissues of the Japanese Black cows fed endophyte infected perennial ryegrass straw. Cow 1 was fed the straw ad libitum (about $6.5 \mathrm{~kg}$ ) for 15 days. Cows 2, 3 and 4 were received $3 \mathrm{~kg}$ of the straw a day for 5,13 or 16 weeks respectively.

animals of the first group presented the clinical signs that were observed in the field by the feeding of the straw for 12 to 15 days. One cow which showed falling down was killed at day 15 of experiment for the pathological examination. The remaining two cows were separated from the perennial ryegrass straw at same day. Clinical signs of them were diminished within 2 to 3 days after deprivation of the straw. Three cows of the second group were fed the ryegrass straw half as much as the first group for more than five weeks. They showed no clinical signs for ryegrass staggers. These observation suggested that the female Japanese Black cattle is susceptible to lolitrem B. Furthermore, dilution of the toxins with the other feed stuffs should be effective for the prevention of endophyte toxicosis.

In the winter season from 2001 to 2002, endophyte toxicosis brought by fescue straw was occurred at many farms in Oregon ${ }^{16)}$. Professor Craig at the Oregon State University is now analyzing the factors that brought this extreme endophyte toxicosis. Summer in 2001, the Oregon State experienced the worst drought. As the consequence, the cattle were in poor nutrition and in weak condition. Furthermore, the temperatures during the winter were especially cold. The cattle under these conditions might be affected by even lower amount of ergovaline than proposed threshold. As mentioned in previous paragraph, our observation suggested that the female Japanese Black cattle is sensitive to Iolitrem B. Therefore, the toxin threshold value proposed by the Oregon State University should be reevaluated.

\section{Public health problem}

Another endophyte problem of interest is the public health significance of the endophyte toxins. In ruminants, ergopeptine alkaloids, such as ergovaline, can be metabolized by the ruminal microflora. Ergot alkaloids are absorbed rapidly as the lysergic acid amide or bio-transformed 
ergopeptine alkaloids ${ }^{17)}$. Hill et al. ${ }^{18)}$ showed that ruminal tissue has ergot alkaloid transport potential. Transport of alkaloids seems to be an active process. After intravenous administration of ergovaline to sheep, it diminished rapidly from blood ${ }^{19}$. Furthermore, ergovaline can not be detected in the milk of goat received this mycotoxin intravenously ${ }^{20)}$. Urine is the primary excretory route of ergot alkaloids in the cattle $\mathrm{e}^{17)}$. These findings are suggesting the low possibility of the contamination of milk with ergot alkaloids.

As for lolitrems, their pharmacokinetics in cattle is unknown. To know the fate of lolitrem $B$, we determined lolitrem B concentrations in several organs and tissue of the Japanese Black cows fed perennial ryegrass straw. Lolitrem B was not detected in muscle, liver, kidney, lung and cerebrum of the cattle showing the symptoms of ryegrass staggers (a cow of group 1 of the feeding experiment mentioned in the previous section). In contrast, fat tissue around kidney contained $210 \mathrm{ppb}$ of lolitrem B. Small amounts of lolitrem B less than $150 \mathrm{ppb}$ were detected even in the fat tissue of the cattle without clinical signs (group 2 of the feeding experiment in the previous section). This observation indicates that lolitrem B will not accumulate in major edible parts of beef cattle. Therefore, the neurotoxic effect of lolitrem B to human through beef is unlikely. However, further research is needed to make clear the fate of lolitrems in the cattle.

Furthermore, carcinogenicity, mutagenicity, teratogenicity and other toxicities of the chemicals produced by endophyte should be examined to secure the safety of the meat or milk produced by cattle consuming endophyte-infected perennial ryegrass or tall fescue.

\section{References}

1 ) Powell, R.G., Petroski, R.J.: Nat. Toxins, 1, 163-170 (1992)

2 ) Gallagher, R.T., Hawkes, A.D., Steyn, P.S., Vleggaar, R.: J. Chem. Soc., Chem. Commun., 614-616 (1984)

3 ) Gallagher, R.T., White, E.P., M ortimer, P.H.: N. Z. Vet. J., 29, 189-190 (1981)

4 ) Keogh, R.G.: N. Z. J. Exp. Agric., 1, 55-57 (1973)

5 ) Galey, F.D., Tracy, M .L., Craigmill, A.L., Barr, B.C., M arkegard, G., Peterson, R., O'Connor, M.: J. Am. Vet. Med. Assoc., 199, $466-470$ (1991)

6 ) M unday, B.L., M onkhouse, I.M ., Gallagher, R.T.: Aust. Vet. J., 62, 207 (1985)

7 ) Yates, S.G , Plattner, R.D., Garner, G.B.: J. Agric. Food Chem., 33, 719-722 (1985)

8 ) Schillo, K.K., Leshin, L.S., Boling, J.A., Gay, N.: J. Anim. Sci., 66, 713-718. (1988)

9 ) Stamm, M .M., DelCurto, T., Horney, M R., Brandyberry, S.D. Barton, R.K.: J. Anim. Sci., 72, 1068-1075 (1994)

10) Schmidt, S. P., Osborn, T.G.: Agric. Ecosys. Environ., 44, 233-262 (1993)

11) Nakamine, M., Asato, H., Koshimoto, H., Ono, M ., Nakamura, M., Nitta, Y., Shoji, K., Shirai, Y., M iyazaki, S.: J. Clin. Vet. M ed. (Rinshojyuui), 16, $38-45$ (1998) (In Japanese)

12) Enomoto, S., Miyazaki, S.: J. Vet. Clin.(Kachikushinnryo), 46, 421-427 (1999) (In Japanese with English summary)

13) Pearson, E.G., Andreasen, C.B., Blythe, L.L. and Craig, A.M.: J. Am. Vet. Med. Assoc., 209, 1137-1142. (1996)

14) Turner, B., Conklin, F., Carrol, D., DelCurto, T., Cross, T.: Special Report 952, Agricultural Experiment 
Station, Oregon State University, pp.13-16 (1995)

15) M iyazaki, S., Fukumura, M., Yoshioka, M., Yamanaka, N .: J. Vet. M ed. Sci., 63, 1013-1015 (2001)

16) News paper article available from: URL:http:// www.oregonlive.com/ news/ oregonian/ index.ssf?/ xml/ story.ssf/ html_standard.xsl?/ base/ news/ 102232822977310.xml

17) Stuedemann, J.A., Hill, N.S., Thompson, F.N., Fayrer-Hosken, R.A., Hay, W.P., Dawe, D.L., Seman, D.H., Martin, S.A.: J. Anim. Sci., 76, 2146-2154 (1998)

18) Hill, N.S., Thompson, F.N., Stuedmann, J.A., Rottinghaus, G.W., Ju, H.J ., Dawe, D.L., Hiatt, E.E.: J. Anim. Sci., 79, 542-549 (2001)

19) Jaussaud, P., Durix, A., Videmann, B., Vigie, A., Bony, S.: J. Chromatogr. A, 815, 147-153 (1998)

20) Durix, A., Jaussaud, P., Garcia, P., Bonnaire, Y., Bony, S.: J. Chromatogr. B Biomed. Sci. Appl., 729, 255263 (1999)

エンドファイト中毒に関する最近の話題

宮崎 茂: 独立行政法人 農業技術研究機構 動物衛生研究所 (305-0856 つくば市観音台 3-1-5)

イネ科牧草に感染する真菌エンドファイトが産生するマイコトキシンによる草食家畜の中毒は, アメリ カやニージーランドで大きな問題となっている.我が国では, 1997 年から 1998 年にかけて, アメリカから 輸入したペレニアルライグラスストローによる牛および馬のエンドファイト中毒が発生した . これを契機 に, 輸入業者の多くがストローのエンドファイト毒素濃度チェックを実施しているが, 弚の後もエンド ファイト中毒が散発している．本稿では，我が国で発生したエンドファイト中毒について概説するととも に, エンドファイト中毒予防上の問題点, エンドファイトが産生するマイコトキシンの畜産物への残留の 可能性等について考察する.

キーワード : ロリトレム , エルゴバリン , 麦角アルカロイド , ペレニアルライグラス , トールフェスク 